\title{
The Brazilian beef supply chain and food security: a productive inputs view
}

\author{
A cadeia produtiva da carne bovina brasileira e a segurança alimentar: um ollhar para os insumos \\ produtivos \\ La cadena productiva de carne de vacuno brasileña y la seguridad alimentaria: una mirada a los \\ insumos de producción
}

Yasmin Gomes Casagranda

ORCID: https://orcid.org/0000-0001-9363-9716 Federal University of Mato Grosso do Sul, Brazil

E-mail: yasmin.casagranda@ufms.br

Giana de Vargas Mores

ORCID: https://orcid.org/0000-0003-3733-2220

Federal University of Mato Grosso do Sul, Brazil IMED Business School, Brazil E-mail: gimores@gmail.com

Eduardo Luís Casarotto

ORCID: https://orcid.org/0000-0001-5729-4263 Federal University of Grande Dourados, Brazil E-mail: eduardocasarotto@ufgd.edu.br Leila Dal Moro ORCID: https://orcid.org/0000-0003-0456-4260 IMED Business School, Brazil

E-mail: leidalmoro@yahoo.com.br

Ana Flávia Siqueira Abrahão

ORCID: https://orcid.org/0000-0002-0479-1837 Federal University of Mato Grosso do Sul, Brazil E-mail: anaflavia.abrahao@gmail.com

Guilherme Cunha Malafaia

ORCID: https://orcid.org/0000-0001-8565-1053 Brazilian Agricultural Research Corporation, Brazil E-mail: guilherme.malafaia@embrapa.br

\begin{abstract}
The alignment of food production systems with the trends and demands of the world population plays an important global role. This study aims to discuss the convergence of trends related to the Brazilian beef cattle supply chain from a food security perspective. Therefore, it includes important reports on the future of this supply chain and its input production, taking on a qualitative approach to consider trends in animal health, genetics, nutrition, forage, and farm machinery in terms of the development of Brazilian agriculture and the future of food and agribusiness. From a managerial point of view, it was possible to provide information capable of leading to a sustainable understanding. Thus, a content analysis of the documents was carried out, coding them through the Sustainable Development Goals and categorizing them by taking into account the 2030 Agenda's five Ps (people, planet, prosperity, peace, and partnerships). Along this line, the discussion highlights the themes of poverty and climate change, emphasizing them with regard to the categorization social aspects - the $\mathrm{P}$ of people). Future trends will require a workforce prepared to deal with the additional limitations that can arise with the use of new technologies as productivity increases.
\end{abstract}

Keywords: Production chain; Stages; Production inputs; Livestock; Sustainability.

\section{Resumo}

O alinhamento dos sistemas de produção de alimentos com as tendências e demandas da população mundial desempenha um importante papel em nível global. Este estudo tem como objetivo discutir a convergência de tendências relacionadas à cadeia produtiva da carne bovina brasileira na perspectiva da segurança alimentar. Para tanto, compreende importantes relatórios sobre o futuro dessa cadeia produtiva e de seus insumos, a partir da abordagem qualitativa para considerar tendências em: saúde animal, genética, nutrição, forragem e máquinas agrícolas no desenvolvimento da agricultura brasileira e no futuro da alimentação e dos agronegócios. Do ponto de vista gerencial, foi possível fornecer informações capazes de levar a um entendimento sustentável. Assim, a análise de conteúdo dos documentos foi realizada, codificando-os por meio dos Objetivos de Desenvolvimento Sustentável e categorizando-os, levando em consideração os cinco Ps da Agenda 2030 (pessoas, planeta, prosperidade, paz e parcerias). Nessa linha, a discussão destaca os temas pobreza e mudanças climáticas, enfatizando-os no que diz 
respeito à categorização de aspectos sociais - o $\mathrm{P}$ de pessoas. As tendências exigirão uma força de trabalho preparada para lidar com as limitações adicionais que podem surgir com o uso de novas tecnologias à medida que a produtividade aumenta.

Palavras-chave: Cadeia produtiva; Estágios; Insumos produtivos; Pecuária; Sustentabilidade.

\section{Resumen}

La alineación de los sistemas de producción de alimentos con las tendencias y demandas de la población mundial desempeña un papel global importante. Este estudio tiene como objetivo discutir la convergencia de tendencias relacionadas con la cadena productiva de carne vacuna brasileña desde la perspectiva de la seguridad alimentaria. Por lo tanto, comprende importantes informes sobre el futuro de esta cadena productiva y sus insumos, desde un enfoque cualitativo para considerar tendencias en: salud animal, genética, nutrición, forrajes y maquinaria agrícola en el desarrollo de la agricultura brasileña y en el futuro de la alimentación y agroindustria. Desde el punto de vista de la gestión, fue posible proporcionar información capaz de conducir a una comprensión sostenible. Así, se realizó el análisis de contenido de los documentos, codificándolos a través de los Objetivos de Desarrollo Sostenible y categorizándolos, tomando en cuenta los cinco Ps de la Agenda 2030 (personas, planeta, prosperidad, paz y alianzas). En esta línea, la discusión destaca los temas de pobreza y cambio climático, enfatizándolos en la categorización de los aspectos sociales - P de las personas. Las tendencias requerirán una fuerza laboral preparada para hacer frente a las limitaciones adicionales que pueden surgir del uso de nuevas tecnologías a medida que aumenta la productividad.

Palabras clave: Cadena productiva; Etapas; Insumos productivos; Ganado; Sustentabilidad.

\section{Introduction}

Global beef consumption has increased over the past 50 years. The Organization for Economic Cooperation and Development (OECD, 2019) indicates that world beef production will grow around $1.28 \%$ per year until 2027, increasing the total to 79.3 million tons. Brazil will strengthen its position among the main beef producers until 2040 (Embrapa, 2020). The sector seeks to increase production with the use of new technologies and the reduction in area of land used. The country stands out in its efforts to improve production with quality, supported mainly by genetics, health, and management.

Brazil is recognized for its thriving agriculture that designates it as one of the major world food producers. Despite this, the country has undergone changes over the past decade that have affected its structure and production (IBGE, 2019). Beef cattle farming plays an important part in this movement; for example, the clearing of new pasture areas has contributed to the increase in the number of farms since 1950. The states of Rio de Janeiro, São Paulo, and Minas Gerais are characterized by the old occupations, so the process of opening pasture areas occurred through the areas being occupied by crops. The areas considered new agricultural frontiers, however, have directly influenced the expansion of livestock activity, especially the use of the Cerrado region in the Midwest (Embrapa, 2020).

The Food and Agriculture Organization of the United Nations (FAO, 2017a) points out that the world population will reach 9.7 billion by 2050, with two-thirds of the population living in urban areas. This growth generates pressure on agricultural production, since the need for wider production can result in the degradation of natural resources. The FAO report details trends for the future of agricultural systems concerning food and livelihood. Most of these trends are interdependent and form a group of challenges for achieving food security and sustainable agriculture (FAO, 2017a).

In the document "2014-2034 vision: The future of technological development in Brazilian agriculture", Embrapa's Strategic Intelligence System (Agropensa, 2014) contemplated some of the trends proposed by FAO. This report anticipates ways in which FAO's concerns can be addressed through technological development in food supply chains (FAO, 2017a). Aligned with these publications, the Beef Cattle Intelligence Center (CiCarne) presented the 2020 publication "The future of the Brazilian beef cattle supply chain: A vision for 2040" in order to contribute to public and private policies, as well as the research, development, and innovation agenda for science and technology institutions (Embrapa, 2020).

Given this context, this study aims to discuss the convergence of trends related to the beef cattle supply chain from a food security perspective. As a result, the paper considers these reports/documents for the future of the supply chain and its input production. In addition, it is important to engage in achieving the goals proposed by the Sustainable Development Goals 
(SDGs) (UN, 2021), covering - in some way, whether theoretical or practical - the themes that are crucial in this context of food security and more sustainable production.

\section{Methodology}

This study is a qualitative approach, using secondary data from the following documents: i) "2014-2034 vision: The future of technological development in Brazilian agriculture" (Agropensa, 2014); ii) "The future of food and agriculture: Trends and challenges" (FAO, 2017a); iii) "The future of the Brazilian beef cattle supply chain: A vision for 2040" (Embrapa, 2020). The study uses trends for the input stage of the supply chain as a basis for analysis within a food security perspective. Based on the ideas of each document, it was possible to develop a discussion among the convergences of their contents.

Agropensa organizes its prospective studies by macro-themes oriented from the perspective of the supply chain, providing a basis for the analysis of technological challenges in different agricultural supply chains. This reveals a supply chain pressured by markets, sectorial policies, and rural development. On the other hand, the supply chain is equipped with tools, resources, and emerging technological innovations to meet product supply needs (food, in this case). The decision to use the 2014 version of the Agropensa report rather the 2018 version is due the fact that it precedes the FAO report and raises the concerns of the Brazilian researchers about future scenarios of agriculture in the country.

The aforementioned FAO report (2017) presents 15 trends for the future of food and livelihoods in agricultural systems: 1) population growth, urbanization, and aging; 2) economic growth accelerating food transitions by increasing agricultural demand; 3) increased competition for natural resources; 4) climate change; 5) agricultural productivity and innovation; 6) transboundary pests and diseases; 7) conflicts, crises, and natural disasters; 8) poverty, inequity, and food insecurity; 9) nutrition and health; 10) structural changes and employment; 11) agriculture migration and feminization; 12) change in food systems; 13) food losses and waste; 14) governance of food security and nutrition; 15) financing for development.

The scenario presented by FAO (2017a) is challenging for each of these segments. In this context, the "The future of the Brazilian beef cattle supply chain: A vision for 2040" report focuses on the inputs stage. The CiCarne document presents strategic information on set trends that will affect the beef cattle supply chain, analyzing the external environment, which is consolidated into ten megatrends: 1) biological ahead of low-waste management; 2) biotechnology transforming beef farming; 3) less grass and more meat; 4) profit based on animal welfare; 5) consolidated livestock with major players; 6) slaughterhouses becoming more natural and demanding of quality; 7) meat with designation of origin; 8) digital transformation of the entire supply chain; 9) lack of qualified labor; 10) Brazil as a major exporter of meat and genetics.

This research analyzes the three documents and their interrelated contents (Figure 1). The results are described in Section 3, showing the points of convergence and the elements that still need to be studied in-depth. In a complementary way, the discussion of trends for supply chains aimed at the input stage of raising cattle includes questions regarding the vision and expectations of the Sustainable Development Goals of the United Nations (UN). In this sense, a content analysis is carried out, presenting the most emphasized points in the three documents studied, as well as their meanings. The three stages of content analysis were followed by: i) pre-analysis and organization of documents; ii) exploration of these materials through coding and enumeration; iii) treatment of results, considering categorization, frequency, interpretation, and discussions (Bardin, 2011). Some themes of the SDGs are not addressed in the documents and, as a result, were not considered in the subsequent analyses.

\section{Results and Discussion}

In consideration of the future scenario, the Brazilian beef supply chain should continue constantly developing, 
supported by innovative technologies to meet future demands and social and environmental commitments. The reports were organized according to their publication dates, and Figure 1 highlights the convergent points between them.

Figure 1 - Trends for supply chains in food security.

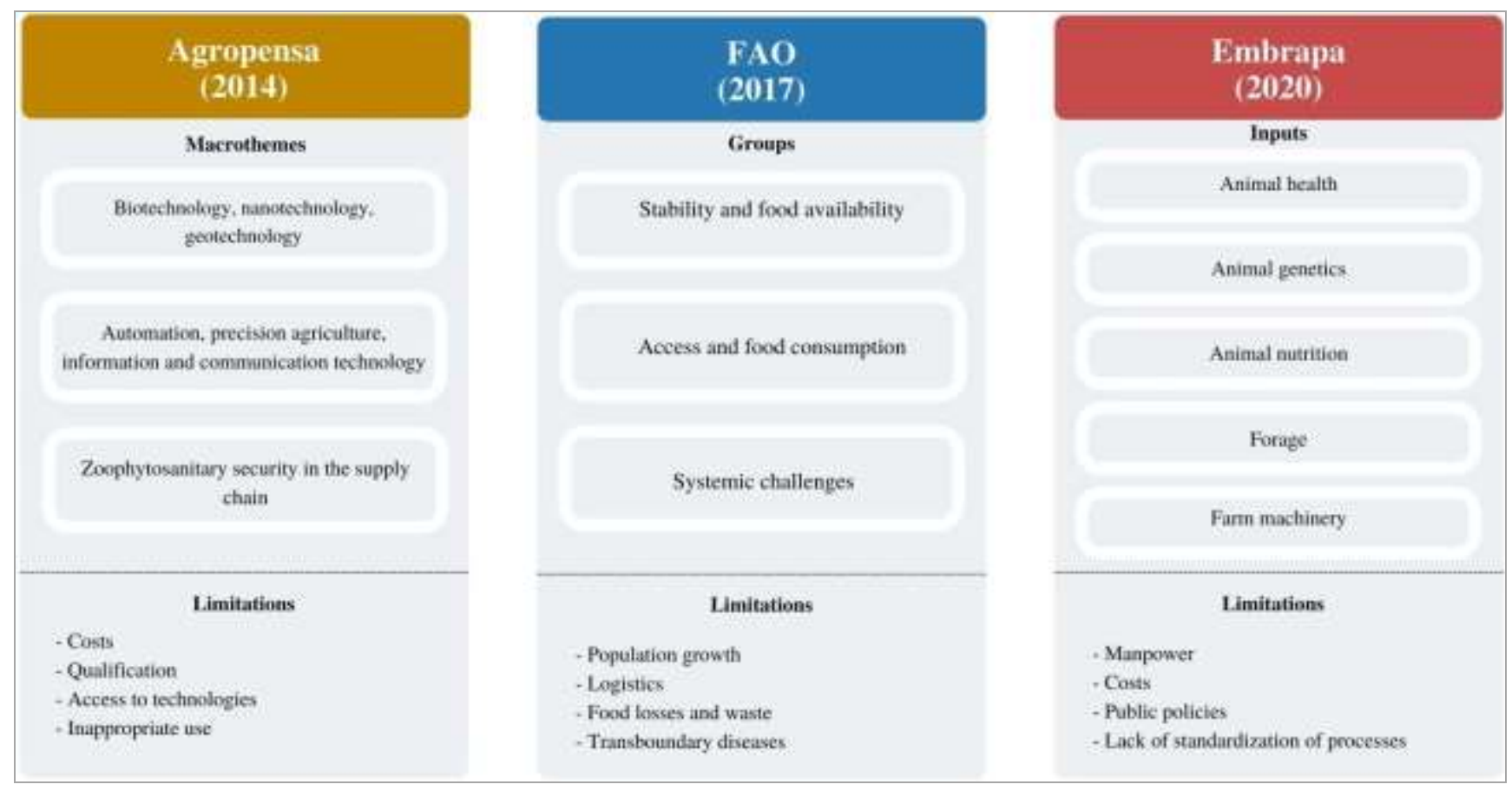

Source: Elaborated by authors (2021).

The Agropensa report covers the technological innovations in the field of agricultural/agribusiness production in order to meet future needs for sustainability. The CiCarne report takes a similar perspective, specifically for the beef cattle supply chain. Both encourage discussion and the rethinking of production, industry, and marketing to serve the global population for food and alleviate the concerns FAO raises in its report.

Figure 1 shows the convergence of issues from the strategic groups addressed by the FAO report: i) population growth with aging and urbanization, which compromise agricultural sectors such as employment and income, especially in Africa and Asia; ii) logistics issues for storage, transport, and marketing; iii) a third of what is produced is lost or wasted along the food supply chains; iv) transboundary diseases and pests, such as types of calamities that increase with the flow of people, animals, plants, and agricultural products between regions, representing a threat to human health and compromising food security (FAO, 2017a). In this sense, it describes the relationship between the three documents in the following subsections. The topics are the trends for the input stage of the beef cattle supply chain proposed by Embrapa (2020), as it is the latest report of the three.

\subsection{Animal health}

Public policies are essential for the promotion of new strategies. The eradication of diseases is linked to the sector's economy, since the spread of such maladies results in losses of productivity (Galanakis, 2020). Intensive production systems require the use of antibiotics; there is a risk associated with the animals' resistance to such antibiotics and the increase in potential for zoonotic diseases (FAO, 2017a). In this sense, the requirement of certain vaccines will likely remain until 2040 (Embrapa, 2020). Despite their low occurrence, brucellosis, tuberculosis, and foot-and-mouth disease are examples of diseases 
that require state control to raise awareness among producers, since good sanitary conditions are sine qua non for beef exports (Ferreira Neto et al., 2016). In addition, parasitic diseases are still the cause of collective efforts regarding animal health.

A tropical country is fertile ground for the proliferation of ticks (Keesing, Allan, Young, \& Ostfeld, 2013). Scientists have been conducting research into this infestation, which spreads across the country, continually extending its reach. Therefore, many possible solutions have been developed, from new drugs to genetic alternatives. By 2040, important measures must be taken in an attempt to control this parasitic disease, including the implementation of new surveillance systems (Embrapa, 2020). One of the options has biological origins, which, in addition to meeting sustainability policies, meets the demands of consumers in terms of good production practices.

Legal control measures involve antibiotics, as they affect hormones. The legislation continues to prohibit the use of anabolic steroids in beef cattle, though it is uncertain whether the understanding of this topic will change before 2040. Although farmers support the movement to implement the regular use of anabolic steroids in livestock, the consumer's expectation is the opposite: the demand for more natural meat is growing (Embrapa, 2020).

The push for sustainability continues to protect the environment regarding the implementation of reverse logistics with veterinary medicines. Petitions and other movements have made it clear there is a requirement for greater control over the marketing of veterinary products. The inadequacy of the reverse logistics is a possible obstacle for Brazilian meat in the world market, given the damage caused to the environment. These barriers need to be overcome to meet sustainability, food safety, and food security issues. Improving the quality of Brazilian meat depends on technical-scientific investment to develop and become more competitive (Embrapa, 2020).

\subsection{Animal genetics}

Genetics and its engineering can be the basis for primordial solutions in meat production, such as the presence of genetically modified animals in Brazil's herds. This reality can be analyzed in studies due to the influence that these animals will have on the biomes (Embrapa, 2020). The increased need to solve productivity problems and to decrease the use of chemical products will be one of the highlights, as both are related to the population's dependence on them, as well as safety and ethics in animal welfare (Embrapa, 2020). Science can contribute to improving animals so that the needs of each market niche are met, including the use of reproductive biotechniques to increase productive profitability, shorten generations, and improve cattle handling and meat quality.

Disease prevention and control are associated with advanced genetic engineering technologies, which can come in the form of marker vaccines, DNA mutations, synthetic biology, and advances in diagnosis (Agropensa, 2014). Scientific biotechnology uses improvements in cattle production to serve as a basis for solving problems such as hunger (Medialdea et al., 2018). The use of high-quality genetics by certified breeders and management grouping have been accepted as techniques to improve productivity and chronological efficiency (Embrapa, 2020). In this context, genetic modification can help to increase production and productivity (FAO, 2017a).

The dissemination of cloning and biotechnology are both moderate in Brazil, with some problems related to the technique, but there is the prospect of expansion with the advancement of research on the topic (Embrapa, 2020). Recently, long-read sequencing technologies have emerged, leading to less complex ways to reassemble the bovine reference genome (Bickhart et al., 2020).

\subsection{Animal nutrition}

In terms of animal nutrition, there is a prospect of increasing the use of mineral supplementation in the country. Due to meat production intensification, farmers' knowledge, and the doses of supplements, this will be reflected in the industry 
related to the sale of these products (Embrapa, 2020). Due to this trend, pasture management and crop integration techniques should be improved; with less advanced infrastructure, supplementation will be necessary. The understanding of agents and conditions related to the integration of cultures becomes essential for policy implementation, as well as for the intensification of strategies (Gil, Garrett, \& Berger, 2016).

This theme is a consequence of the regularization of products as animal feed. With this, there will be a need for inspection to prove good production practices for the consolidation of these products in the foreign market. Biotechnology innovations can be consolidated by scientific findings and technological implementations (Embrapa, 2020). In addition, they increase the possibility of intensifying gains in the productivity of domestic plants and national animals by reducing the occurrence of damage caused by pests, diseases, and invaders in agricultural production systems (Agropensa, 2014).

\subsection{Forage}

In recent decades, the amount of researchers with the objective of improving Brazilian pastures has been growing, which includes an increase in patents for the sector. It is possible to infer that forage seeds are developed, but it is not yet possible to measure if productivity will be superior to the existing productivity in the market (Embrapa, 2020). Among the main concerns is the search for characteristics that can increase productivity. The development of new technologies contributes to this context, mainly in the dissemination of more productive genetic materials for forage plants (Agropensa, 2014).

Based on adequate management techniques and public policies affecting the producers, it is possible to increase production and, at the same time, prevent deforestation (Veloso et al., 2020). In tropical pastures, there is a high incidence of intrusive plants, which is why cleaning is mainly carried out mechanically. As there can be risks to livestock, such as intoxication or loss of production with the ingestion of forage, cleaning is not carried out in some cases. The application of pesticides can generate excessive costs and unfavorable commercial pressures; in this case, rotation is an alternative to promoting constant renewal (Embrapa, 2020).

Biodefense measures and their dissemination are a trend and include meeting cleaning needs, environmental preservation, commercial pressures, and difficulties with conventional techniques. There is a growing body of research on this technique, providing guidance on developing new molecules and training people to use them (Embrapa, 2020).

\subsection{Farm machinery}

Regarding machinery, precision technologies have been developed in line with the best production practices (Pivoto et al., 2017). Autonomous machines and remotely controlled equipment can lead to quicker processes, precision in operation, and fewer risks and accidents. Investments related to trends in technological innovations can generate specific machines for each productive sector by using precision agriculture, nanotechnology, and the internet of things (Embrapa, 2020).

The specificities of productive systems can be observed in confinement, integration, and semi-confinement. It is possible to find new techniques for using infrared video thermography data to measure the herd temperature in real time (Cuthbertson, Tarr, \& González, 2019), which can be developed to detect diseases (Kim, Min, \& Choi, 2019).

Drones have expanded their market in global agribusiness (Talaviya et al., 2020). The use of different sensors, image capture developed the process that had been carried out by satellites. The investment is considered low and can be a differential for greater productivity and profitability in the production of beef cattle in Brazil. The improvement in communicability with an inclination towards new skills facilitates the relationship between countryside, city, society, and science (Agropensa, 2014).

Another possibility is robots in the field, which have the potential to improve productivity rates and address the problems with labor shortages. The trend points to the expansion of its use in the guided integration of robots into animal 
handling practices (Embrapa, 2020). The use of technologies has limitations, especially regarding the financial resources for their adoption (FAO, 2017a).

\subsection{Connection with SDGs}

There are many concepts in the literature for defining the importance of food security, sustainable production, and the challenges of population growth. Therefore, it is important to present the association and inference of the data through a more detailed analysis. Table 1 presents a diagnosis of the three documents covered in this research in relation to sustainable factors, taking as a parameter the content analysis, according to Bardin (2011).

Table 1 - Document content analysis (Agropensa, FAO, Embrapa).

\begin{tabular}{clcccc}
\hline SDG & (Codification) Record unit & $\begin{array}{c}\text { Enumeration } \\
\text { Agropensa }\end{array}$ & $\begin{array}{c}\text { Enumeration } \\
\text { FAO }\end{array}$ & $\begin{array}{c}\text { Enumeration } \\
\text { Embrapa }\end{array}$ & Categorization \\
\hline SDG 1 & Poverty & 6 & 129 & 0 & People \\
SDG 2 & Hunger/sustainable agriculture & 1 & $6 / 13$ & 5 & People \\
SDG 3 & Health & 37 & 87 & 24 & People \\
SDG 4 & Education & 4 & 17 & 0 & People \\
SDG 5 & Gender equality & 0 & 35 & 0 & People \\
SDG 6 & Water & 48 & 70 & 8 & Planet \\
SDG 7 & Energy & 43 & 51 & 11 & Planet \\
SDG 8 & Economic growth & 0 & 36 & 0 & Prosperity \\
SDG 9 & Industry, innovation, and infrastructure & $82 / 125 / 8$ & $20 / 34 / 28$ & $38 / 5 / 8$ & Prosperity \\
SDG 12 & Sustainable consumption and & 2 & $2 / 3$ & 1 & Planet \\
& production & 3 & 179 & 2 & Planet \\
SDG 13 & Climate change & 13 & 10 & 6 & Partnership \\
SDG 17 & Partnerships & Planet: $33 \%$ & Prosperity: $17 \%$ & Partnership: $8 \%$ & Peace: 0\% \\
\hline \multicolumn{2}{c}{ Frequency of categories: 12=100\% } & People: $42 \%$ & & \\
\hline
\end{tabular}

Note: ${ }^{1}$ Enumeration: refers to the number of repetitions of registration units during the analysis of documents. Source: Elaborated by authors (2021).

Through the content analysis carried out in the three documents (Agropensa, FAO, Embrapa), it is possible to analyze the issues addressed by the UN's SDGs. Firstly, the SDG themes most mentioned in the documents (codification) are poverty $(n=129)$, and climate change $(n=179)$. It highlights that both themes were focused on the FAO document. The context unit is mentioned twice: “In FAO's view, there are 10 key challenges that need to be addressed if we are to succeed in eradicating hunger and poverty, while making agriculture and food systems sustainable" (FAO, 2017b, p. 7), and "The impacts of climate change are being felt, and - if left unabated - will intensify considerably in the years ahead. Globally integrated production processes have brought many benefits, but present challenges in terms of their regulation and the need to steer them towards more equitable and sustainable outcomes" (FAO, 2017b, p. 3).

In the categorization, the SDGs were divided into the 2030 Agenda's five P's: people, planet, prosperity, peace, and partnerships (UN, 2021). In this way, it is possible to analyze social, economic, and environmental approaches. For instance, people (SDGs 1, 2, 3, 4, 5, and 10), planet (SDGs 6, 7, 12,13, 14, and 15), prosperity (SDGs 8, 9, and 11), partnerships (SDG 17). In evaluating what is most mentioned in terms of categories, the $P$ for people stands out with $42 \%$, indicating the emphasis on the social aspects addressed by the documents. Aspects that are more representative are sought about the importance of research to assist and promote local and global food security where the population has healthy food, with sufficient quality and quantity (Dal Moro \& Brandli, 2020).

\section{Final Considerations}

Advances in the method and process of agricultural production will be responsible for meeting food needs in the 
future. Current expectations include more accessibility to the new techniques discussed through incentives and public credits for investments. Costs can be a limiting factor for farmers, as the resulting financial return is uncertain. This point refers to changes in the production process due to the implementation of new technologies in each of the areas studied. This limitation makes food security assistance a worrying issue.

Farming will continue to be a process of transformation in which the farm is no longer just a unit producing raw materials. It becomes a technological development laboratory with intensive use of technologies such as information, smart farming, the internet of things, and big data.

Genetic improvement, from the perspective of genome editing - precision genetic manipulation used as an alternative or combined with the development of transgenic technology - will be a source of competitive responses for the development of new proposals in the beef supply chain. Another opportunity will be the use of high-precision equipment for monitoring and managing the farm, which will collect and store information; the equipment not only collects data, but processes tasks such as planting, fertilization, spraying, harvesting, and transportation - in many cases, with no human interference.

Future trends will require a workforce prepared to deal with additional limitations that can arise with the use of new technologies as productivity increases. Another conclusion is related to the content analysis, taking into account the SDGs (coding), the 5 Ps of the 2030 Agenda and, thus, the themes addressed throughout the three documents found when a descriptive analysis is performed in the study. The themes of poverty followed by climate change are highlighted, which can be emphasized with regard to the categorization of social aspects - the P of people.

\section{Acknowledgments}

This work was supported by the National Council for Scientific and Technological Development (CNPq - Brazil) [grant number 420981/2018-7] and the Federal University of Grande Dourados (Brazil).

\section{References}

Bardin, L. (2011). Análise de conteúdo. Edições 70.

Bickhart, D. et al. (2020). Advances in sequencing technology herald a new frontier in cattle genomics and genome-enabled selection. Journal of Dairy Science, 103(6), 5278-5290. https://doi.org/10.3168/jds.2019-17693.

Brazilian Agricultural Research Corporation, Embrapa. (2020). O futuro da cadeia produtiva da carne bovina brasileira: uma visão para 2040. Embrapa Gado de Corte.

Brazilian Institute of Geography and Statistics, IBGE. (2019). Produção da pecuária municipal. https://sidra.ibge.gov.br/pesquisa/ppm/quadros/brasil/2019

Centro de Estudos Avançados em Economia Aplicada, Cepea. (2021). PIB do agronegócio alcança participação de 26,6\% no PIB brasileiro em 2020. 2021. Esalq/USP. https://www.cepea.esalq.usp.br/upload/kceditor/files/Cepea_CNA_relatorio_2020.pdf

Cuthbertson, H., Tarr, G., \& González, L. A. (2019). Methodology for data processing and analysis techniques of infrared video thermography used to measure cattle temperature in real time. Computers and Electronics in Agriculture, 167, 105019. https://doi.org/10.1016/j.compag.2019.105019.

Dal Moro, L., \& Brandli, L. L. (2020). Potentialities and challenges of family agriculture in a region of South Brazil. International Journal of Sustainable Development and World Ecology, 27, 129-139. https://doi.org/10.1080/13504509.2019.1679275.

Embrapa's Strategic Intelligence System, Agropensa. (2014). Visão 2014-2034: o futuro do desenvolvimento tecnológico da agricultura brasileira. Brasília: Embrapa.

Ferreira Neto, J. S. F. et al. (2016). Analysis of 15 years of the national program for the control and eradication of animal brucellosis and tuberculosis, Brazil. Semina: Ciências Agrárias, 37(5), 3385-3402. http://dx.doi.org/10.5433/1679-0359.2016v37n5Supl2p3385.

Food and Agriculture Organization of the United Nations, FAO. (2017a). The future of food and agriculture: trends and challenges. Rome: Food and Agriculture Organization of the United Nations.

Food and Agriculture Organization of the United Nations, FAO. (2017b). The state of food security and nutrition in the world: building resilience for peace and food security. FAO, IFAD, UNICEF, WFP, WHO.

Galanakis, C. M. (2020). The food systems in the era of the coronavirus (Covid-19) pandemic crisis. Foods, 9(4), 523. https://doi.org/10.3390/foods9040523. 
Research, Society and Development, v. 10, n. 13, e260101320895, 2021

(CC BY 4.0) | ISSN 2525-3409 | DOI: http://dx.doi.org/10.33448/rsd-v10i13.20895

Gil, J. D. B., Garrett, R., \& Berger, T. (2016). Determinants of crop-livestock integration in Brazil: evidence from the household and regional levels. Land Use Policy, 59, 557-568. https://doi.org/10.1016/j.landusepol.2016.09.022.

Keesing, F, Allan, B. F., Young, T. P., \& Ostfeld, R. S. (2013). Effects of wildlife and cattle on tick abundance in central Kenya. Ecological Applications, 23, 1410-1418. https://doi.org/10.1890/12-1607.1.

Kim, H., Min, Y., \& Choi, B. (2019). Real-time temperature monitoring for the early detection of mastitis in dairy cattle: methods and case researches. Computers and Electronics in Agriculture, 162, 119-125. https://doi.org/10.1016/j.compag.2019.04.004.

Medialdea, J. et al. (2018). Potential of science to address the hunger issue: ecology, biotechnology, cattle breeding and the large pantry of the sea. Journal of Innovation \& Knowledge, 3(2), 82-89. https://doi.org/10.1016/j.jik.2017.12.007.

Organization for Economic Cooperation and Development, OECD. (2019). OECD-FAO Agricultural outlook $2018-2027$. https://stats.oecd.org/index.aspx?DatasetCode=HIGH_AGLINK_2018\#

Pivoto, D., Waquil, P. D., Talamini, E., Finocchio, C. P. S., Dalla Corte, V. F., \& Mores, G. V. (2018). Scientific development of smart farming technologies and their application in Brazil. Information Processing in Agriculture, 5(1), 21-32. https://doi.org/10.1016/j.inpa.2017.12.002.

Talaviya, T., Shah, D., Patel, N., Yagnik, H., \& Shah, M. (2020). Implementation of artificial intelligence in agriculture for optimisation of irrigation and application of pesticides and herbicides. Artificial Intelligence in Agriculture, 4, 58-73. https://doi.org/10.1016/j.aiia.2020.04.002.

United Nations, UN. (2021). The 17 Sustainable Development Goals. https://sdgs.un.org/goals

Veloso, G. A. et al. (2020). Modelling gross primary productivity in tropical savanna pasturelands for livestock intensification in Brazil. Remote Sensing Applications: Society and Environment, 17, 100288. https://doi.org/10.1016/j.rsase.2020.100288. 